\title{
How undemocratic is the House of Lords?
}

Sonali Campion, Sean Kippin and the Democratic Audit team examine how the UK'S deeply controversial current second chamber, the House of Lords, matches up to the criteria for liberal democracies with bicameral legislatures. Now an almost-all appointed Chamber, the Lords has achieved recent prominence on Brexit and tax credits by exerting some bipartisan influence moderating Commons proposals. However, its members remain creatures of patronage, and wholly unaccountable to the UK's citizens. All parties except the Tories now support its replacement by an elected Senate. Increasingly only the Tories and Liberal Democrats are still appointing any peers - although there are also a fifth of peers who are 'crossbenchers', not taking a party whip.

\section{What does democracy require for second chambers in legislatures?}

All legislators with a capacity to approve, amend or reject legislation should:

- $\quad$ either (and preferably) be directly elected by voters, or

- be elected/appointed indirectly by the elected chamber, or by a government fully accountable to the elected chamber.

In a liberal democracy no legislator should sit in a second chamber (or upper house) simply by virtue of their birth, wealth or as a result of donating money or services to party politicians.

Serving in the second chamber may confer distinction, but no part of the legislature should form an integral part of an aristocratic or societal honours system.

Any appointment of legislators to a second chamber should be vetted by a genuinely independent regulatory body. Mechanisms should be in place to remove legislators who breach legal or ethical standards and to ensure the social and partisan representativeness of all groups. 
In any bicameral legislature, an upper house should be designed to realise a combination of specific constitutional and political advantages. A second house should:

- Act as a constitutional and policy check on the majority in the elected house, especially by offering a safeguard against legislative changes that breach democratic principles, impair rights or are otherwise ill-advised.

- Facilitate the technical operation of legislative drafting, scrutiny and amendment. Improve the accountability of the executive as a whole to the legislature and to public opinion.

- Increase the number or range of access channels from civil society to the executive, in equitable and accountable ways.

- Re-balance the geographical representation of different parts of the country compared with the lower house - for instance, to secure more equal or greater influence for all component regions/provinces/states within a country.

- Improve the social representativeness of legislators.

- Widen the range of expertise amongst legislators as a whole.

- Provide a mechanism to encourage the continued engagement of 'emeritus' politicians in public life.

- Offer a measure of policy continuity, especially on issues where civil society actors must make decisions with some long-run predictability.

\section{Recent developments}

The UK's House of Lords is an almost all-appointed upper chamber, whose members are nominated by some (but not all) main parties. Once appointed they effectively sit for life and attend more or less when they wish, never facing re-appointment, nor of course any form of re-election. The Lords' powers in law-making are limited to amending or delaying nonfinancial bills, and its members have generally followed a convention acknowledging the 'primacy' of the Commons. In addition, the 'Salisbury convention' means that the House will give a second reading to bills for which an elected government in the House of Commons has a majority and a manifesto commitment.

In the flurry of Brexit legislation tabled in parliament's 2017-18 session most observers did not expect that the House of Lords would play a very consequential role, given that both the Conservative government and the Labour Party had campaigned at the 2017 election on a platform of implementing the UK's exit from the EU. However, by the end of the process, the government had been defeated 15 times in some fairly significant Lords votes, which some observers felt had the effect of forcing MPs to face up to some vital constitutional choices. On some of these generally 'pro-Remainer' changes the government accepted a need for change and introduced their own versions of them. Others were more or less reversed in the Commons, but not without difficulty and with additional concessions extracted from Theresa May and ministers by both right-wing 
Brexiteers and liberal Remainers in the Tory party. As a result, the Lords earned some new critics in the right-wing Brexiteer press (previously amongst its great defenders).

Clearly then the House of Lords still matters in UK legislative politics, but on what basis? The pro-Remain majorities in the Lords essentially reflected the feelings of UK elites at the historic periods when members were appointed, with most of them occurring in the 43 years 1973-2016 when the UK seemed a secure member of the EU. As well as pro-EU Liberal Democrats (now massively over-represented in the Lords relative to their current popular support), most long-established Tory and Labour peers are pro-Remain.

Meanwhile the third largest party in the House of Commons since 2015, the SNP, refuses to nominate anyone for appointment to the Lords, and because UKIP has never secured any significant MPs at elections (despite gaining $13 \%$ of votes in Britain in 2015) it too is represented there only by two or three Tory defectors. The SNP stance has been followed (almost) by Jeremy Corbyn as Labour leader since 2015. He has made only four appointments on specific grounds, promised to scrap the Lords as currently constituted, and required all new appointees to vote for creating an elected House in future. A prospect thus opens up of the Lords becoming just a two-party (Conservative/Liberal Democrat) House, representing only England, mitigated for the moment only by the 'legacy' group of 'cross-bencher' peers and past Labour nominees.

\section{Strengths, Weaknesses, Opportunities, Threats (SWOT) analysis}

\section{Current strengths}

In recent years, while observing the primacy of the Commons, and the 'Salisbury convention' to respect government's clear general election mandates, the House of Lords has proved willing to defeat ministers, even on flagship and other significant pieces of legislation. This change has led to somewhat greater checks and balances constitutionally and a little more scrutiny in the policy-making process, especially on matters not presaged in a winning party's manifesto.

There have been some highly questionable appointments of peers over time, even in recent years. Still a substantial part of the public, many MPs and elites, and the Lords members themselves (almost universally) believe that peers bring valuable additional expertise into public life.

\section{Current weaknesses}

The House of Lords remains completely unelected. All peers can hold their seats until they die (if they want to) and thus are not accountable to or removable by citizens in any way. However, peers can now 'retire' if they wish to from the Lords (but still use its facilities as a London 'club') and some members have taken this course.

The value of patronage power for Prime Ministers and party leaders means that the Lords has increased hugely in size (see below). Costs are also substantial the average peer claims over $£ 25,800$ in expenses and allowances per year. One recent investigation also revealed that 15 peers had claimed an average of $£ 11,090$ each, despite not speaking in the main chamber during the 2016-17 session. 


\section{Current strengths}

The social diversity of membership in the House of Lords has slightly improved in this century. In 2018 there are now 204 female peers ( $26 \%$ of the total). In 2017 there were 51 black or minority ethnic peers $(6 \%$ at that date).

\section{Current weaknesses}

Although outside peerage appointments are scrutinised by a weak regulator (the House of Lords Appointments Commission), party nominations of peers seem to be only lightly and inadequately appraised, and HOLAC's remit is very constrained. Many citizens and commentators believe that major party donors can still effectively 'buy' peerages.

Corruption and misbehaviour allegations against peers highlight the openness to abuse that inevitably follows when legislators are accountable to no one and lack any effective oversight.

Ministers from the Lords are not held accountable to the same degree as their counterparts in the Commons.

In all 91 hereditary peers still sit in the Lords, with vacancies supposedly being 'elected' from a wider pool of hereditaries who cannot sit. In effect this is just a self-perpetuating oligarchy selecting new members from among the aristocracy with a tiny 'electorate'.

Uniquely amongst UK religions, 26 Church of England bishops still have seats in the Lords.

\section{Future opportunities}

All parties in the centre and on the left of UK politics are now committed to scrapping the Lords in favour of a wholly elected Senate.

Systems of election using PR systems, and detailed possible rules and conventions for regulating a Senate's relations with the Commons and roles in policy-making, have now been worked out. This weakens many of the traditional arguments put forward by Lords' defenders (pointing to small advantages of existing bicameralism as if they would be lost altogether, or suggesting that reform must create new tensions between the chambers).

\section{Future threats}

The Conservatives remain resistant to any substantial reform of the Lords of any kind, but especially to introduce elections.

Most existing peers will undoubtedly seek to wreck any serious reform of the chamber, resisting to the last ditch (as illustrated by the survival of 91 hereditaries). 


\section{Future opportunities}

After the 2014 Scottish independence referendum, and the ad hoc EVEL (English votes for English laws) changes of 2015, the urgent need to reach a proper devolution settlement for all parts of the UK opens up a potentially key new constitutional role for an elected Senate. Greater devolution of Whitehall powers to English city-regions may also help in this area.

Lord Grocott has made persistent efforts to abolish the hereditary by-elections system, introducing a private member's bill in the 2015-16 session (which was blocked at committee stage). Grocott tried again in the 2017-18 session. Some critics argue that the move is not a reform, but just designed to make the status quo seem more palatable.

\section{Future threats}

It seems likely that any substantial reform will need to be put to a referendum, at which only a coherent and low-cost scheme could succeed - and for which there is not yet consensus agreement between the parties or in public opinion.

\section{The unelected and swollen House of Lords}

In 2012, the coalition government introduced the House of Lords Reform Bill to the House of Commons. The Bill would have created a smaller House of Lords in which a large majority of representatives would be elected by a system of proportional representation, but where a substantial minority of peers would be appointed more or less as they are now. Additionally, space would be reserved for appointed 'ministerial members' and Church of England bishops. The reforms were essentially wrecked by the opposition of Conservative backbench MPs, combined with the refusal of the Parliamentary Labour Party to facilitate debate (citing opposition to the proposed timetable rather than the substance of the reforms). Some minor reforms were introduced in $\mathbf{2 0 1 4}$ to enable peers' voluntary retirement, to exclude those given a prison sentence of more than a year, and to allow peers to be excluded if they did not attend the House for an entire session.

Calls for reform have persisted, particularly since the deputy speaker Lord Sewel was forced to resign, following revelations that he had been filmed taking drugs with sex workers and commenting in derogatory terms on the Lords' expenses system. Widespread public and media outrage over a string of misconduct incidents, and unease over the role of party political donations in securing peerages for governing party supporters especially, have been backed up by continued demands for a major reform of the House of Lords. The Liberal Democrats are firm in wanting a democratically elected chamber (but nonetheless have a full quota of members themselves). The Scottish National Party refuses point blank to make any party nominations. Their deliberate and long-term absence makes the Lords even more grossly unrepresentative and south-east England-centric than ever. Figure 1 shows the current party make-up of the House. 


\section{Figure 1: The Lords by party or group in 2018}

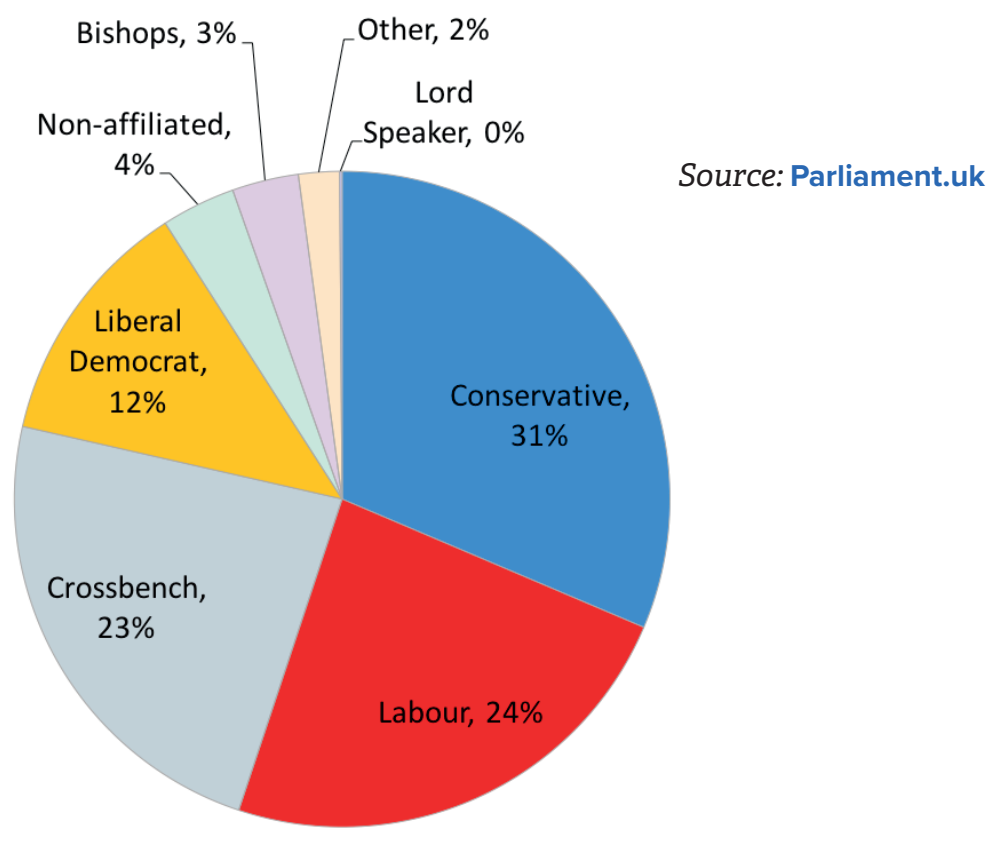

For Prime Ministers and opposition leaders alike, the ability to appoint peers (without any limit) has been politically convenient. David Cameron created new peers faster than any of his predecessors, following a policy that the membership of the House of Lords should be roughly in proportion to the party voting totals at House of Commons elections. In 2018 there were 793 peers - the only other countries in the world with second chambers larger than the first are the People's Republic of China, Kazakhstan and Burkina Faso - none of them liberal democracies. Figure 2 shows the size of the Lords in between 1992 and 2016; the vertical line indicates most hereditary members were removed in 2000. By 2016 the total possible peers attending increased by $27 \%$ and amongst actual eligible members the increase was $27 \%$. (Absolute members include those who have retired, or taken leave of absence - it can be seen that in recent years the orange line has again risen above the grey line of actual membership.) There is a constant tendency for potential members to decrease, as elderly peers die, offset by bouts of Prime Ministers creating new peers for their party (and pro rata-ing for other parties making nominations). Public criticism of rising numbers has led to a small decline in recent years.

During the 2010-15 coalition, both Tory and Liberal Democrat peers tended to support their government's legislative proposals, so that with limited crossbench backing most laws could pass unscathed. However, after the 2015 general election, Cameron's Conservative majority government and later Theresa May's minority Tory government have had the support of less than a third of peers. Both faced Labour and Liberal Democrat peers in opposition (nearly two-fifths of the House). 
Figure 2: House of Lords membership and attendance from 1992 to 2016

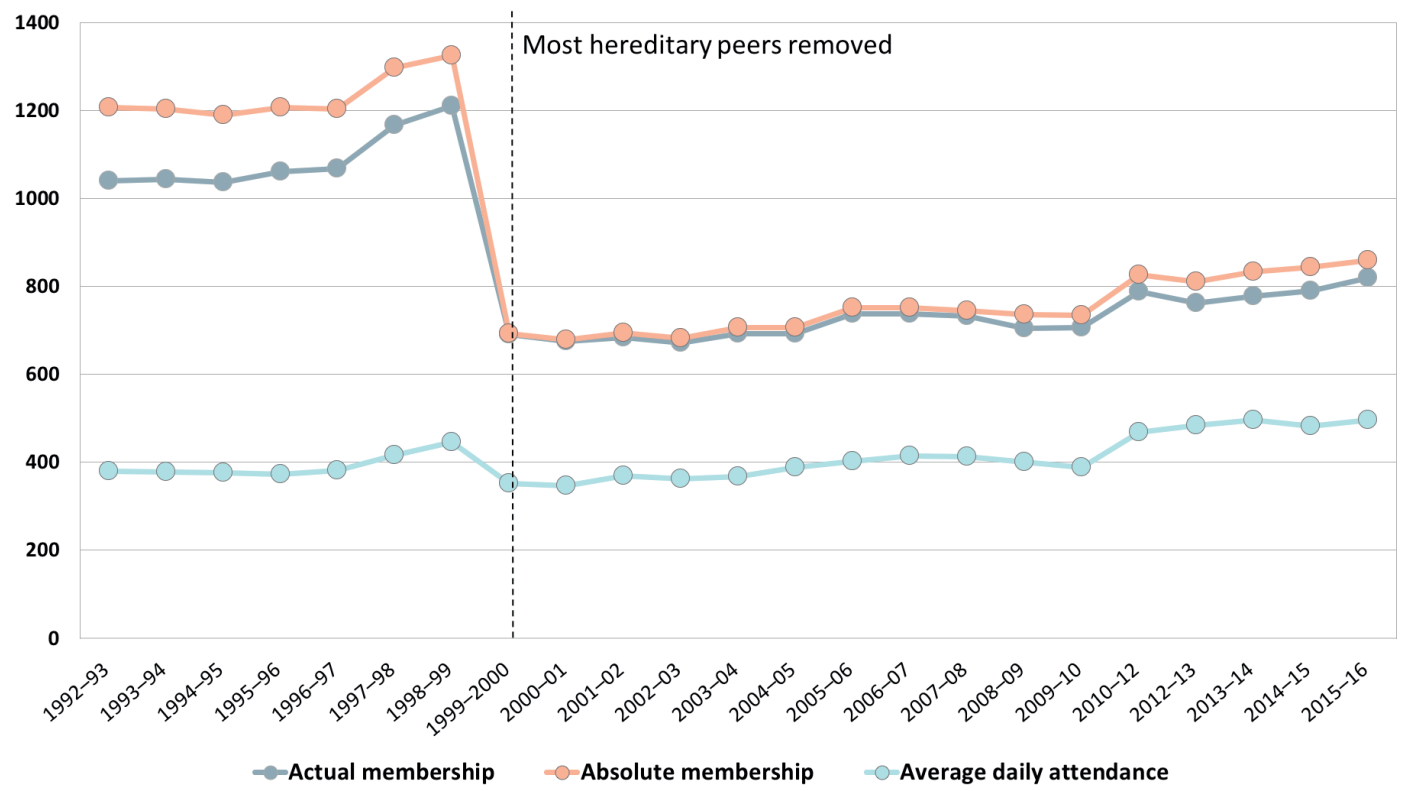

Source: Russell, Taylor, Size of the House of Lords, House of Lords Library note, 2016

Notes: The dotted line here marks the 2000 exclusion of most hereditary peers from the House.

To cope with this, Cameron appointed 40 more peers (of whom 26 were Conservatives) in the 2015 dissolution honours and a further 16 (13 of them Conservative) in his resignation honours. This final list attracted particular criticism for its alleged 'cronyism', with a number of key Conservative aides and donors awarded peerages. The only Labour nominee, Shami Chakrabarti, had chaired an inquiry that largely cleared the party of charges of anti-semitism three months earlier. In total, Cameron appointed 190 peers during his premiership, a faster rate than any Prime Minister before him. May has slowed the rate, but in early 2018 appointed nine new peers, three of them former Tory ministers.

These efforts to increase Tory representation did not prevent ministers being defeated 98 times in the Lords between May 2015 and June 2017, compared to 99 times in the previous five years of coalition. Yet in August 2015 Cameron dismissed the question of Lords reform and reiterated his ad hoc scheme for the numbers of peers to 'reflect the situation in the House of Commons'. In 2016 the Lords speaker, Lord Fowler, argued that the increase in the Lords' size was 'hard to justify', and called on ministers to stop 'faffing around' with the House's oversized condition. After 2016 May's Brexit legislation also created some large defeats in the Lords of major government plans, often backed by Conservative Remainer peers (see above). 


\section{Issues around membership}

Analysis by the SNP showed that nearly three-quarters of the 62 peers appointed in the second half of 2015 were former MPs, special advisors or party aides. Only four academics and two NGO or third-sector figures entered the Lords in this time, suggesting that little diversity or expertise is being brought into play by the current House. Just over a quarter of eligible peers are women and only $6.4 \%$ are black or minority ethnic. Territorial representation is particularly poor, with limited representation of those outside the southeast of England. After a flurry of appointments during the 2000s, the House of Lords Appointments Commission - which has only appointed crossbenchers - has been told to recommend only two new appointments each year; in 2016 there were none. The only other parliamentary chamber in the world to include representatives from the state religion is the Islamic Republic of Iran.

By 2020 more than a quarter (211) of peers will be over 80, and Lord Steel has suggested introducing a retirement age. However, Meg Russell has pointed out that this measure if adopted alone would lead to an uneven party balance, and would not prevent Prime Ministers from appointing large numbers of new peers to replace them. Even simply imposing a cap on numbers would reduce the proportion of crossbenchers, since Prime Ministers tend to appoint overwhelmingly from their own party.

The only other parliamentary chambers in the world to still include hereditary members of the aristocracy are in the tiny polities of Tonga and the Kingdom of Lesotho. An attempt to end the hereditary peerage by-elections, in which some or all of the House picks replacements to top up the remaining 91 hereditary peers after one dies, also failed in late 2016 after not receiving government support. It was revived in 2017-18 and, if successful, would mean that the number of hereditary peers would gradually dwindle as their current eligible members die off.

\section{Ministers in the House of Lords}

At present, around one in five ministers, 20 in all, sit in the Lords and are accountable only to other peers, providing no direct link between them and voters to create legitimacy and accountability. Currently no Secretaries of State sit in the House of Lords, but in the recent past important figures were there - for example, Peter Mandelson was virtually Deputy PM there in 2009-10, and Business Secretary before that in 2008-9. However, the only form of scrutiny of peer ministers by MPs is currently through the Commons committees, which very infrequently ask them to give evidence. A possible reform would be to allow ministers from the Lords to answer MPs' questions in the House of Commons or in Westminster Hall.

\section{Independence of the House of Lords}

Defenders of the chamber argue that it continues to act with a reasonable degree of independence from the government, as shown by the difficult ride given to the controversial Health and Social Care Bill in 2012 (in contrast to its easy passage through the House of Commons), when peers mauled ministers' proposals, which contributed to 
a 'pause', re-consultation and some redesign of the legislation, as well as the tax credits defeat in autumn 2015 (discussed below). In 2016, the Lords rebelled over the right of EU citizens to stay in the UK after Brexit, which were followed by extensive Brexit legislation defeats for the government in the 2017-18 session. This development towards a more even-handed scrutiny has come as something of a shock the Conservatives, who always dominated the Lords under the hereditary system and so were therefore used to suffering far fewer defeats when in power than Labour governments did.

Furthermore, Lords defeats since 2010 have frequently been on significant pieces of legislation including some relating to immigration, pensions, anti-lobbying, financial services, children and families, welfare reform and legal aid. In some of these cases the amendments passed by the Lords, or the amended government proposals responding to Lords defeats, were accepted by the Commons, often bringing about better policymaking. The pattern of defeats and amendments suggest that the Lords continues to play a significant legislative role on issues where the heavily whipped MPs in the Commons at times seem incapable or unwilling to act.

\section{The 2015 revolt on tax credits and 'Strathclyde review'}

Most of the time amendments moved in the Lords are reversed in the Commons under governments with a majority, of which 2015-17 is the only recent example. However, in October 2015 peers very unusually voted to delay changes to tax credits until certain conditions were met - in the process verging into budgetary matters where normally they have no competence. This move sparked outrage from Conservative ministers, who argued that peers were overstepping their constitutional powers by meddling with a budgetary matter (albeit intended to be implemented via delegated legislation). Opposition peers countered that the legislation was not a money bill but a statutory instrument, a method seemingly chosen by the government so as to avoid debate and amendment in the Commons, while the cuts themselves were in violation of election pledges given by leading Tories that tax credits would not be changed. Therefore, they argued, it was within their rights to ask the government to rethink. The former chancellor, George Osborne, subsequently made a virtue out of dropping the tax credit cuts in his Autumn Statement.

Nonetheless Cameron set up an inquiry led by the former Tory peers' leader Lord Strathclyde 'to conduct a review of statutory instruments and to consider how more certainty and clarity could be brought to their passage through Parliament' as a result of the dispute. The resulting Strathclyde Review report in December 2015 recommended that the Lords' (very rarely used) ability to veto statutory instruments should be scrapped, bringing these powers into line with the House's powers over primary legislation, where peers can only delay action for a year. These contentious recommendations were received with scepticism by the opposition, and were widely criticised for threatening to undermine parliamentary scrutiny of secondary legislation. Theresa May's government dropped the recommendations a year later, but with the proviso that they might be revived if peers failed to show 'discipline and self-regulation' and continued to veto statutory instruments. 


\section{Expenses abuse in the House of Lords}

The House of Lords periodically hits the headlines due to expenses scandals which highlight the on-going openness of the Upper House to financial misuse. In 2014 Lord Hanningfield was suspended for a year after being convicted of abusing expenses for a second time (he served time in prison for his first offence in 2011). Worryingly, Hanningfield offered to reveal another 50 peers who were also claiming allowances for days when they undertook no work in the Lords, although he did not actually name anyone when pressed. He also claimed: 'I was unaware that what I was doing was wrong'. In 2015, alongside the allegations that Lord Sewel had spent public money on drugs and sex workers (see above), the Lord Speaker, Baroness D'Souza, also came under fire for her 'downright frivolous' attitude to public money. An FOI request revealed she had fuelled substantial 'unnecessary' spending on ministerial cars and international travel.

\section{Proposals for Lords reform}

In its 2017 manifesto, Labour called for a democratically elected second chamber and, in the interim, the removal of the last hereditary peers (mostly Tories) and a 'wider package of constitutional reform' that would reduce the size of the House. Subsequently Corbyn insisted that any new Labour appointees must pledge to vote for a wholly elected second chamber in future.

The Liberal Democrats previously reiterated a commitment to reform based on proposals in the failed 2012 Bill, but their 2017 manifesto was clearer in calling for an elected chamber, a call joined by the Greens. The SNP and UKIP manifestos in 2017 supported scrapping the Lords altogether.

However, in their 2015 manifesto the Conservatives recognised only the case for 'introducing an elected element', but emphasised this would not be a priority. Cameron flatly refused to discuss reform on the scale demanded by the opposition parties. Some commentators, including Lord Tebbit and Meg Russell, have even suggested Cameron might have deliberately undermined the Lords through his numerous appointments.

In their 2017 manifesto the Tories declared that 'comprehensive reform' of the House of Lords is 'not a priority'. How long the Tories can go on defending an unreformed House when essentially all the other parties have withdrawn most legitimacy from Lords remains one of the great questions of British politics. All the other parties' stances seem to recognise the past attempts at 'tweaking the Lords' have not addressed the chamber's systemic problems, and it is likely that only a fresh, elected Senate can really bring about the changes that are needed. 


\section{Conclusions}

New Labour's compromise changes to keep only a self-perpetuating oligarchy of hereditary peers in the House of Lords and to move it to being an overwhelmingly appointed-for-life body appear to have perhaps increased its role and significance. However, the case for reform is also now impossible to ignore. The growth in Lords membership and costs is unsustainable, its territorial representation is lamentable, the UK's fourth-largest party is boycotting it, and the current members lack all democratic accountability and legitimacy.

The Lords are now sustained only by Conservative party support, its convenience as a source of Prime Ministerial patronage and the still-significant barriers to meaningful reform. If current government quiescence and the self-interested opposition of peers themselves are to be overcome, opposition parties favouring major reform need to crystallise (and coordinate) their proposals for replacing the Lords with an elected Senate, potentially through a constitutional convention.

Sonali Campion is a former editor of Democratic Audit and the UCL Constitution Unit blog. She now works at the Commonwealth Secretariat.

Sean Kippin is a PhD candidate and Associate Lecturer at the University of the West of Scotland and a former editor of Democratic Audit.

Additional research was provided by Richard Reid (Australian National University), Ros Taylor (Democratic Audit editor in 2017) and Patrick Dunleavy (co-Director of Democratic Audit UK). 